\title{
RECENZJE
}

ADAM ŚWIEŻYŃSKI

\section{(rec.) Michał Jakub Wagner, „Interpretacje rozwoju biologii ewolucyjnej na przełomie XIX i XX wieku", Liber Libri, Warszawa 2020, ss. 3321}

\begin{abstract}
Streszczenie. Autor omawianej publikacji podjął się zadania przeanalizowania zaproponowanych dotąd interpretacji „zaćmienia darwinizmu”, chcąc ustalić, w jakim stopniu odpowiadają one rzeczywistości. Po dokonaniu ustaleń w tym zakresie doszedł do wniosku, że żadna z nich nie wyjaśnia w sposób adekwatny załamania się, jakie dotknęło teorię Darwina we wspomnianym okresie. Dlatego postanowił zaproponować własną interpretację „zaćmienia darwinizmu”, w której odwołuje się przede wszystkim do filozoficznych uwarunkowań darwinowskiej teorii ewolucji.
\end{abstract}

Słowa kluczowe: teoria ewolucji; darwinizm; biologia ewolucyjna; zaćmienie darwinizmu

W powszechnym odbiorze społecznym pojawienie się i rozwój darwinowskiej teorii ewolucji są postrzegane jako jedno z przełomowych wydarzeń w rozwoju nauki. Doniosłość i aktualne znaczenie tej teorii spowodowały, że niekiedy zapomina się o tym, iż jej akceptacja przez środowisko naukowe nie dokonała się bez oporów, a nawet prób jej całkowitego odrzucenia. W dyskusjach nad nią zazwyczaj zwraca się uwagę na aspekt światopoglądowy, który generował (i wciąż generuje) dyskusje dotyczące możliwości uzgodnienia naukowo-ewolucyjnego obrazu świata z obrazem teologiczno-kreacjonistycznym. Dyskusje te niejednokrotnie prowadziły do prób zakwestionowania darwinizmu z pozycji teistycznych. Okazuje się jednak, że darwinizm, już wkrótce po swoim pojawieniu się, napotkał na rozmaite przeciwności ze strony samych przyrodników, którzy poszukiwali rozwiązania problemu rozwoju życia na Ziemi. To właśnie spory, które rozgorzały między

1 Publikacja jest dostępna na stronie wydawnictwa: https://liberilibri.pl/interpretacje -rozwoju-biologii-ewolucyjnej. 
przyrodnikami, wydają się w gruncie rzeczy najbardziej interesujące i pouczające, gdy chodzi o badanie rozwoju nauki, a w szczególności biologii ewolucyjnej. Pokazują one bowiem, że przyrodnicza teoria Darwina była (i wciąż jest) głęboko uwikłana w problematykę filozoficzną, a konkretnie w kwestię przyjmowanych przez poszczególnych badaczy założeń i przedzałożeń o charakterze filozoficznym. Należy sądzić, że taki stan dotyczy także innych teorii naukowych, w tym również tych o szczególnym znaczeniu dla rozwoju współczesnego naukowego obrazu świata.

Publikacja Michała Wagnera, w której autor podjął właśnie ten aspekt natury i rozwoju darwinowskiej teorii ewolucji, dotyczy szczególnego okresu w historii rozwoju biologii ewolucyjnej z przełomu XIX i XX wieku, określanego w literaturze przedmiotu „zaćmieniem darwinizmu”. „Zaćmienie” to, w opinii badaczy, objawiło się nagłym spadkiem zainteresowania teorią ewolucji autorstwa Karola Darwina na rzecz innych, niedarwinowskich koncepcji ewolucyjnych, takich jak: neolamarkizm, ortogeneza, saltacjonizm i mutacjonizm. Po śmierci Darwina w 1882 roku społeczność naukowa zaczęła coraz bardziej odchodzić od jego koncepcji, uznając, iż jego teoria nie daje się uzasadnić w perspektywie ówcześnie dostępnych danych empirycznych. Stąd też postulowano stworzenie nowych koncepcji ewolucyjnych, które trafniej wyjaśniałyby zjawisko ewolucji życia. Powstałe pod koniec XIX wieku nowe dziedziny naukowe, w szczególności paleontologia i genetyka, również funkcjonowały w opozycji do darwinizmu, tworząc odmienne koncepcje rozwoju życia. Sytuacja ta zmieniła się dopiero w latach trzydziestych XX wieku, kiedy powstała tzw. „syntetyczna teoria ewolucji”. Biologowie tworzący ujęcie syntetyczne, udowodnili, że teoria Darwina jest kompatybilna z rozwijającą się genetyką i w połączeniu z nią jest w stanie rozwiązać wiele problemów występujących w paleontologii, taksonomii i botanice. Wyniki badań przyrodników tworzących syntetyczną teorię ewolucji zostały podsumowane przez Juliana Huxleya w książce 
Evolution: The modern synthesis z 1942 roku. Data ta stała się również symbolicznym momentem końca okresu „zaćmienia” darwinizmu.

Autor omawianej publikacji podjął się zadania przeanalizowania zaproponowanych dotąd interpretacji „zaćmienia darwinizmu”, chcąc ustalić, w jakim stopniu odpowiadają one rzeczywistości. Po dokonaniu rozpoznania w tym zakresie doszedł do wniosku, że żadna z nich nie wyjaśnia w sposób adekwatny załamania się, jakie dotknęło teorię Darwina we wspomnianym okresie. Dlatego postanowił zaproponować własną interpretację „zaćmienia darwinizmu”, w której odwołuje się do historycznych i filozoficznych uwarunkowań darwinowskiej teorii ewolucji.

Zdaniem autora publikacji problematyczność wspomnianego okresu rozwoju biologii ewolucyjnej bierze się głównie stąd, iż „Zaćmienie" zakończyło się nie z powodu odkrycia jakiegoś nowego faktu, istotnego pod względem naukowym, który pozwoliłby na utworzenie syntetycznej teorii ewolucji. W rzeczywistości jedynie na nowo zreinterpretowano znane już wcześniej dane empiryczne. M. Wagner zauważa więc, że zasadniczy problem, przed jakim staje historyk i filozof nauki analizując ten okres, brzmi następująco: dlaczego te same dane empiryczne, które posłużyły do potwierdzenia syntetycznej teorii ewolucji, były używane wcześniej do tworzenia koncepcji będących do niej w opozycji (to znaczy antydarwinowskich)? Autor publikacji stwierdza, że większość historyków i filozofów nauki, próbując odpowiedzieć na pytanie, dlaczego darwinizm został we wspomnianym okresie odrzucony na rzecz innych teorii, wskazuje na liczne czynniki pozanaukowe, które miały wpłynąć na sposób, w jaki ówcześni naukowcy go oceniali. Z kolei to, na jakie czynniki wskazują badacze, jest uzależnione od przyjętych przez nich koncepcji filozoficznych na temat rozwoju nauki w ogóle. Ponadto przyjmowane przedzałożenia filozoficzne wpływają na sposób, w jaki interpretuje się dane historyczne, często doprowadzając do ich zniekształcenia. Zatem podstawowym celem, jaki postawił przed soba autor omawianej publikacji, jest analiza krytyczna najważniejszych 
interpretacji okresu „zaćmienia” darwinizmu ze szczególnym uwzględnieniem przyjmowanych w nich założeń filozoficznych.

$\mathrm{Na}$ zasadniczą treść książki składają się cztery rozdziały, a problematyka poruszana w jej kolejnych fragmentach została podzielona na następujące zagadnienia: zarys okresu „zaćmienia” darwinizmu wraz z prezentacją zarówno teorii Darwina, jak i powstałych wtedy ewolucjonistycznych teorii niedarwinowskich (rozdział pierwszy); przedstawienie najbardziej znanych interpretacji tego okresu, pojawiających się w historii i filozofii biologii (rozdział drugi); analiza krytyczna tych interpretacji (rozdział trzeci); zaproponowanie nowej perspektywy interpretacyjnej i przeprowadzenie filozoficznej analizy genezy tego okresu w historii biologii ewolucyjnej (rozdział czwarty).

Rozdział pierwszy stanowi zarys historyczny omawianego okresu biologii ewolucyjnej. Zostały w nim omówione wczesne, przeddarwinowskie teorie ewolucyjne. W dalszej części zaprezentowano teorię ewolucji autorstwa Karola Darwina oraz ukazano główne inspiracje naukowe, z których czerpał. Dalsze podrozdziały obejmują trzy nurty teorii niedarwinowskich, tworzących „zaćmienie darwinizmu”. W zakończeniu tego fragmentu książki znalazło się wyjaśnienie, w jaki sposób teorie te zostały wyparte przez syntetyczną teorię ewolucji.

Rozdział drugi obejmuje prezentację najważniejszych interpretacji historyczno-filozoficznych omawianego okresu. Pierwszą omawianą przez autora interpretacją jest klasyczna interpretacja autorstwa Ernsta Mayra. Mayr, tłumacząc przyczynę zaistnienia „zaćmienia”, wskazywał na zewnętrzne, irracjonalne czynniki, które uniemożliwiły przyrodnikom pełną akceptację teorii Darwina. Źródłem tych czynników miała być religia, która wzmacniała wiarę w takie szkodliwe (dla teorii Darwina) koncepcje filozoficzne, jak: antropocentryzm, teleologizm, wielki łańcuch bytu czy esencjalizm. Dopiero całkowite odcięcie się od nich w XX wieku pozwoliło na pełną akceptację teorii darwinowskiej. Zdaniem Mayra różnorodność powstałych koncepcji antydarwinowskich w okresie „zaćmienia” wynikała z jednej strony 
z wpływu tychże czynników, z drugiej zaś z bardzo powolnego akceptowania przez przyrodników poszczególnych idei samego Darwina. Według Mayra koncepcja Darwina składała się z różnych elementów, które razem tworzyły jego teorię ewolucji, jak np.: idea ewolucji gatunków, idea wspólnego przodka, idea doboru naturalnego. Mayr stwierdził, iż każdy z tych pomysłów był osobno akceptowany przez przyrodników w ciągu 80. lat od momentu opublikowania O powstawaniu gatunków... (1859). Teorie antydarwinistyczne reprezentowały kolejne stopnie akceptowania poszczególnych elementów darwinizmu, a syntetyczna teoria ewolucji miała być momentem, kiedy udało się ostatecznie zaakceptować je wszystkie.

Kolejną interpretacją, która została zaprezentowana w omawianej książce, jest koncepcja „niedarwinowskiej rewolucji” autorstwa Petera Bowlera. Jego zdaniem teoria ewolucji Darwina była jedną z wielu koncepcji transmutacjonistycznych, które pojawiły się w XIX wieku. To, co się odczytuje się jako „zaćmienie darwinizmu”, jest w rzeczywistości normalną drogą rozwoju biologii ewolucyjnej, która rozpoczęła się wraz z przeddarwinowskimi teoriami J.-B. Lamarcka, R. Chambersa oraz R. Owena. Według tej interpretacji darwinizm stał się popularny dopiero w wersji syntetycznej, a w XIX wieku nigdy nie osiągnął pozycji absolutnie panującego paradygmatu, jak opisywał to Mayr. Tak więc kryzys darwinizmu faktycznie nie zaistniał, gdyż teoria ta nie była dominującą teorią naukową.

Ostatnią zaprezentowaną interpretacją jest idea „interfazy darwinizmu" autorstwa Marka Largenta. Largent, odrzucając zarówno pomysł Mayra, jak i Bowlera stwierdził, że problematyczny charakter etapu „zaćmienia” wynika ze sposobu, w jaki rozumiany jest darwinizm. Historycy, będąc pod dużym wpływem syntetycznej teorii ewolucji, oceniali teorie ją poprzedzające przez jej pryzmat - stąd odnosili mylne wrażenie, iż darwinizm mógł przybrać tylko taką formę. W rzeczywistości wielu z przyrodników, uznawanych dzisiaj za antydarwinistów, utożsamiało się z jego teorią. Largent wychodzi z założenia, iż ideę „zaćmienia” trzeba zupełnie porzucić jako 
określenie błędne. Proponuje on zastąpienie go słowem „interfaza”, zapożyczonym z biologii, a oznaczającym okres życia komórki, gdy ta przygotowuje się do podziału mejotycznego lub mitotycznego. W kontekście historii biologii słowo to miałoby oznaczać etap, w trakcie którego zaczęły być tworzone teorie umożliwiające w dalszej perspektywie powstanie syntetycznej teorii ewolucji.

W rozdziale trzecim znajdujemy analizy krytyczne wyżej przedstawionych interpretacji. W szczególności wykazano, że przyjęte przez historyków modele filozoficzne, dotyczące filozofii nauki, warunkują interpretowanie przez nich omawianego okresu rozwoju biologii ewolucyjnej. Według autora omawianej publikacji w przypadku interpretacji Mayra jest nim pozytywistyczna idea rozwoju nauki, gdzie prawidłowa teoria jest wynikiem prawidłowej interpretacji danych. W tej koncepcji owa prawidłowość ma charakter aczasowy, stąd wszystkie teorie naukowe, niezależnie od okresu, w jakim powstawały, można oceniać przez pryzmat jednej metodologii. W konsekwencji teoria błędna - jak teorie okresu „zaćmienia” - będą wynikiem obiektywnie błędnego sposobu interpretacji danych. Do stworzenia błędnej teorii przyczyniają się ponadto czynniki irracjonalne. W tym ujęciu zadaniem historyka będzie ich rozpoznanie. $\mathrm{Z}$ kolei w interpretacji Bowlera użyty został model rozwoju nauki zaproponowany przez Thomasa Kuhna. Teorie naukowe są zbudowane wokól jednego paradygmatu przyjętego przez daną społeczność naukową. Akceptacja lub odrzucenie teorii będzie uzależnione od tego, czy zgadza się ona z panującym paradygmatem. Uzależniona od niego będzie również budowa teorii naukowych. Na podstawie tej koncepcji zadaniem historyka jest odnalezienie panującego ówcześnie paradygmatu - Bowler rozpoznaje w nim teorię Roberta Chambersa, która wpłynęła na kształtowanie się późniejszych koncepcji okresu „Zaćmienia”, zaś odrzucenie darwinizmu tłumaczy tym, iż nie był on zgodny z panującym paradygmatem. Natomiast koncepcję Largenta można, zdaniem M. Wagnera, powiązać z nominalistycznym podejściem filozoficznym Davida Hulla, który zakładał, iż przynależność 
do danej tradycji badawczej określa sam badacz. Stąd nie można mówić o stałej esencji danego nurtu naukowego, gdyż ta nie składa się z konkretnych pomysłów, a z tworzących ją ludzi. To podejście skupia się na analizie danych historycznych, która ma na celu odtworzenie inspiracji poszczególnych naukowców, grupując ich w ten sposób w pewne siatki powiązań. Znaczenie danej teorii będzie uzależnione od poszczególnego badacza, więc może się zdarzyć, iż do tej samej „siatki” należeć będą naukowcy o zupełnie różnych poglądach (choć inspirujący się tymi samymi problemami). M. Wagner zauważa, że stanowisko Largenta jest najbardziej kontrowersyjne, gdyż nie tylko nie tłumaczy, w jaki sposób tworzą się teorie „błędne”, ale dodatkowo pomija fakt istnienia realnych różnic pomiędzy teoriami w omawianym okresie. Należy je uznać za rozwiązanie „kosmetyczne”, które kosztem utrzymania ciągłej narracji historiograficznej (od Darwina do syntetycznej teorii ewolucji) pomija fakt tworzenia się innych teorii okresu „zaćmienia”. W opinii autora interpretacje Mayra i Bowlera są pod tym względem lepsze, choć i one nie unikają pewnych problemów. W obu tych interpretacjach promuje się esencjalistyczne podejście do historii nauki, tzn. zakłada się, że istnieją esencje, wokół których tworzą się teorie naukowe. Teorie posiadające inne esencje, muszą pozostawać w izolacji w stosunku do reszty. Ponieważ różnice esencjalistyczne występują na poziomie metateoretycznym i dotyczą założeń przyjmowanych w tworzeniu twierdzeń naukowych, racjonalna dyskusja między teoriami nie jest możliwa. Najlepiej widoczne jest to w propozycji Mayra, gdzie tworzenie się opozycji do darwinizmu było wynikiem przyjęcia innego klucza interpretacji danych empirycznych, a nie efektem dyskusji na temat samej teorii Darwina. Dodatkowo w koncepcjach Mayra i Bowlera zakłada się istnienie linii demarkacyjnej rozdzielającej prawidłową, racjonalną interpretację danych od nieprawidłowej, irracjonalnej interpretacji tychże. W przypadku Mayra izolacja teorii niedarwinowskich od „prawidłowej” koncepcji Darwina była spowodowana przyjęciem błędnych przedzałożeń filozoficznych. Prawidłowość teorii Darwina 
polegała na tym, iż nie ingerowały w nią żadne irracjonalne czynniki pozanaukowe. $Z$ kolei w przypadku Bowlera sytuacja jest co prawda odwrócona (dominacja antydarwinizmu przez cały XIX wiek), lecz wyjaśnienie pozostaje podobne. Panujący w XIX wieku paradygmat zawierał w sobie elementy irracjonalne, które nie pozwalały na akceptację koncepcji Darwina. W obu przypadkach przyjęcie istnienia linii demarkacyjnej sprawia, że powstanie „błędnej” teorii ma swoje źródła w irracjonalizmie badaczy. Takie podejście doprowadza do tego, że rozwiązanie problemu powstania „błędnych” teorii zostaje przerzucone na dziedziny, które są w stanie wykazać istnienie irracjonalnych przyczyn sformułowania tych teorii, jak np. psychologia czy socjologia. Nie zakłada się więc tu możliwości rekonstrukcji racjonalnego powstawania teorii „błędnej”.

Analizy wyszczególnionych interpretacji, dokonane przez M. Wagnera, umożliwiły mu wyjaśnienie, w jaki sposób przyjęta filozofia nauki ogranicza i modeluje opis i interpretację historii rozwoju danej dziedziny, jak również posłużyły za punkt wyjścia do zaproponowania autorskiej interpretacji omawianego okresu rozwoju biologii ewolucyjnej w rozdziale czwartym. Zawiera on prezentację nowej interpretacji okresu „zaćmienia” darwinizmu, która, w zamyśle autora, ma uniknąć wyżej wymienionych problemów. Za perspektywę interpretacyjną autor przyjął model siateczkowy rozwoju nauki Larry'ego Laudana. Laudan, tworzący w opozycji zarówno do pozytywistycznego, jak i postmodernistycznego nurtu filozofii nauki (w szczególności T. Kuhna), odrzucił wiele ich założeń. W szczególności zrezygnował z pomysłu istnienia stałych, uniwersalnych zasad, za pomocą których można oceniać poprawność teorii naukowych, a także $z$ istnienia linii demarkacyjnej i w końcu z pomysłu stałej „esencji” teorii. Co najważniejsze, założył, iż w trakcie rozwoju nauki główną rolę odgrywa dyskusja naukowa. W modelu Laudana każda teoria naukowa składa się $\mathrm{z}$ trójelementowej metastruktury stworzonej z przyjętej ontologii, metodologii i aksjologii. Wszystkie te elementy wzajemnie się uzasadniają, więc w przypadku zmiany 
jednego struktura się załamuje i trzeba zmienić kolejne jej elementy. W tej koncepcji zakłada się, że poszczególne elementy nigdy nie są do siebie idealnie dostosowane, zatem zawsze można postulować zamianę jednego z nich, to znaczy dobrać taką metodologię, za pomocą której lepiej zrealizowane zostałyby cele zakładane w aksjologii lub wyznaczyć takie cele naukowe, które byłyby możliwe do zrealizowania w przyjętej wizji świata (ontologii). Każda zmiana skutkować będzie koniecznością zmiany pozostałych elementów metastruktury, która $\mathrm{z}$ kolei objawiać się będzie tworzeniem coraz to nowszych teorii naukowych. M. Wagner zauważa, że ponieważ model Laudana przystosowany jest do analizy dyskusji naukowej, wydaje się być odpowiedni do interpretacji dyskusji pomiędzy darwinistami i antydarwinistami w okresie „Zaćmienia”. Z kolei odrzucenie założeń głównych nurtów filozofii nauki pozwala uniknąć problemów, jakie tworzyły interpretacje Mayra i Bowlera.

Wykorzystując model Laudana, częściowo zmodyfikowany, M. Wagner zinterpretował więc teorie przedstawione w rozdziale pierwszym. Szczególna uwaga została poświęcona sposobowi, w jaki twórcy teorii niedarwinowskich krytykowali Darwina i jakich argumentów w tym celu używali. Warto zauważyć, iż większość argumentacji nie miała charakteru czysto naukowego, w rozumieniu nauk empirycznych. Poruszane przez krytyków kwestie dotykały najczęściej sposobu, w jaki należałoby rozumieć pojęcie gatunku, jakich metod należałoby użyć w badaniu jego przemian i w końcu, co powinno być ostatecznym celem badań naukowych. Tego rodzaju argumenty pozostają nie tylko zgodne z trójelementowym modelem metastruktury Laudana (poruszają kolejno kwestie: ontologiczne, metodologiczne i aksjologiczne), ale również ich występowanie wskazuje na to, co było trudne do zaakceptowania przez XIX-wiecznych przyrodników. Analiza krytyki darwinizmu została przeprowadzona zgodnie z kluczem interpretacji Laudana, to znaczy: w przeciwieństwie do Mayra zakłada się tu, iż krytyka służy nie do obiektywnej oceny teorii, lecz do uzasadnienia potrzeby stworzenia kontrteorii. 
Ponadto specyfika modelu Laudana wskazuje na silne oddziaływanie czynników filozoficznych (jak np. ontologia i aksjologia), które są nieuświadomione i niezależnie od prawidłowości teorii mają ogromny wpływ na jej kształtowanie. Stąd procesu tworzenia teorii nie trzeba redukować do czynników psychologicznych czy też socjologicznych, a można się skupić na analizie filozoficznej.

Zgodnie z interpretacją zaproponowaną przez autora omawianej publikacji teorie niedarwinowskie miały na celu poprawienie istniejącej na metapoziomie sprzeczności w koncepcji Darwina, wynikającej $\mathrm{z}$ nieprawidłowego zastosowania terminów stworzonych w kontekście arystotelizmu do idei zmiennej przyrody. Każdy z nurtów XIX-wiecznego antydarwinizmu tworzył swoją ontologię tak, aby naprawić ten błąd. W neolamarkizmie problem ten rozwiązano, zachowując celowość ewolucji i ideę wielkiego łańcucha bytu, w ortogenezie - postulując istnienie esencji rzędów (lub rodzajów), których gatunki miałyby być jedynie chwilowym wyrazem, zaś w mendelizmie - postulując ideę skoków ewolucyjnych. Zgodnie z modelem Laudana we wszystkich tych nurtach można zauważyć, że zmiana ontologii doprowadziła do kolejnych przemian - szczególnie jest to widoczne w ortogenezie, w której szybko zaproponowano nową aksjologię (która kazała się skupiać na szukaniu stałych praw ewolucji) i mendelizmie, gdzie zaproponowano nową metodologię (skupienie się na badaniach eksperymentalnych).

W konsekwencji powyższych rozważań M. Wagner proponuje nową perspektywę interpretacyjną, w ramach której została podjęta próba odpowiedzi na pytanie: dlaczego „zaćmienie darwinizmu” zaistniało i jak należy rozumieć jego genezę? Hipoteza badawcza autora opierała się na założeniu, że pojawienie się teorii antydarwinistycznych związane było ze specyficznym sposobem interpretacji danych empirycznych, która miała źródło w przyjętych przez ówczesnych przyrodników założeniach filozoficznych. W przeciwieństwie jednak do innych interpretacji okresu „zaćmienia” fakt powstania teorii antydarwinowskich jest rozumiany przez $\mathrm{M}$. Wagnera jako wynik 
racjonalnej dyskusji na temat tego, jaką formę powinna przyjąć akceptowalna (w świetle posiadanych danych empirycznych) koncepcja ewolucyjna. Ukazane więc zostały nieporozumienia mające swoje źródło w samej teorii ewolucji zaproponowanej przez K. Darwina. Darwin, używając terminów i pojęć zakorzenionych w filozofii esencjalizmu (jak np. gatunek), wywołał kontrowersje, gdyż usiłował je zastosować do swojej wizji zmienności przyrody. M. Wagner stara się wykazać, iż różnorodne teorie okresu „zaćmienia” darwinizmu powstały wskutek próby pogodzenia esencjalizmu z ewolucjonizmem, mającej naprawić filozoficzny „błąd” Darwina.

A zatem w ujęciu zaproponowanym przez M. Wagnera „zaćmienie darwinizmu" nie powstało w wyniku oddziaływania czynników ideologicznych czy jakiegoś paradygmatu, lecz było odpowiedzią na sprzeczność, która zachodziła na metapoziomie teorii Darwina. Sprzeczność ta wynikała z zastosowania terminów taksonomii Linneuszowskiej, stworzonych przy założeniu istnienia niezmiennych gatunków, do opisu zmiennej i ewoluującej przyrody. Język, z którego skorzystał Darwin, opisując swoją antyesencjalistyczną wizję gatunku, okazał się być niewspółmierny z zakładaną przez niego ontologią. Odpowiedź na pytanie o przyczynę powstawania gatunków, jaką była teoria doboru naturalnego, można więc było uznać za poprawną jedynie wtedy, gdy zakładano czysto instrumentalną funkcję języka taksonomii, gdyż tylko wtedy można było zignorować zrodzony w wyniku niewspółmierności problem konceptualny. Jednak każdy z kolejnych nurtów ewolucjonizmu niedarwinowskiego tworzył swoje teorie tak, aby ten problem konceptualny rozwiązać, usiłując pogodzić ideę istnienia gatunków o pewnych stałych esencjach $\mathrm{z}$ ideą ich ewolucji.

W tym miejscu należy zgłosić pewną wątpliwość, dotyczącą tego, czy słuszne jest sprowadzenie przez autora książki założeń ontologicznych darwinizmu do jednego i zarazem jedynego elementu, którym okazuje się wizja gatunku. Warto przytoczyć tu stanowisko samego Darwina, który uważał słowo „gatunek” za nazwę dowolnie 
(dla wygody) nadawaną grupie osobników ściśle do siebie podobnych. Współcześni badacze uważają, że pojęcie gatunku nie jest pierwszoplanowym pojęciem w teorii Darwina. Pojęciem takim jest dobór naturalny, który działa na różne grupy zwierzęce i roślinne - powszechnie nazywane populacjami (zob. np. Łastowski, K. (1987). Rozwój teorii erwolucji. Studium metodologiczne. Poznań: Wydawnictwo UAM, 176). Najważniejsze jest dla Darwina to, co dobór "czyni” z populacjami biologicznymi, a to, czym one są, zależy dopiero od doboru naturalnego. $Z$ tego powodu treść pojęcia "gatunek” uwarunkowana jest treścią pojęcia „dobór naturalny”. W tym też sensie pojęcie doboru naturalnego jest bardziej pierwotne niż pojęcie gatunku (czy populacji).

Z uwagi na to, że nie pojawiło się dotąd kompleksowe opracowanie zagadnienia interpretacji okresu „zaćmienia” darwinizmu w literaturze polskiej, zaproponowanie takiego opracowania przez autora omawianej książki wydaje się poznawczo wartościowe, tym bardziej, że dotyka jednego ze szczególnie kontrowersyjnych wątków historii rozwoju biologii ewolucyjnej, który dopiero od niedawna stał się obiektem badań historyków nauki. Analiza tytułowego zagadnienia z punktu widzenia filozoficznego (a nie jedynie historycznego lub historyczno-filozoficznego) jest pierwszą tego rodzaju próbą zrozumienia, jak modele filozoficzne wpływały na kształtowanie się narracji historycznej w przypadku rozwoju darwinizmu. Ukazanie kompleksowego przeglądu różnego rodzaju interpretacji tego okresu, wraz z ich krytyką, jest nowością w polskiej literaturze dotyczącej rozwoju biologii ewolucyjnej. Ponadto, autorską analizę i interpretację okresu „Zaćmienia” należy uznać za nowatorską co najmniej z dwóch powodów. Przede wszystkim jest to pierwsza interpretacja tego typu przeprowadzona za pomocą modelu siateczkowego Larry'ego Laudana. Ponadto jest to pierwsza próba rekonstrukcji procesu powstawania teorii niedarwinowskich na drodze analizy filozoficznej, a nie jedynie rekonstrukcji historycznej. 
Książka Michała Wagnera jest niewątpliwie filozoficznie wartościowa, interesująca oraz metodologicznie wprawnie i adekwatnie opracowana, a jej autor uzyskał oryginalne rozwiązanie problemu naukowego, polegające na zaproponowaniu nowej, autorskiej interpretacji filozoficznej okresu „zaćmienia” darwinizmu. Dostarcza ona nie tylko informacji na temat rozwoju biologii ewolucyjnej na przełomie XIX i XX wieku, ale przede wszystkim wskazuje na mechanizmy i uwarunkowania rozwoju idei i teorii naukowych. Po raz kolejny powraca w niej zasadnicza kwestia, często przeoczana przez przyrodników, a mianowicie rola i znaczenie czynników natury filozoficznej w rozwoju nauk przyrodniczych. Jednocześnie autor „odczarowuje” obraz darwinizmu jako teorii, która powszechnie, w sposób bezproblemowy i natychmiastowy, została zaakceptowana przez środowisko naukowe. Okazuje się bowiem, że rozwój ewolucjonizmu nie miał charakteru „linearnego” i nie następował przez ciągłe poprawianie i udoskonalanie pierwotnego pomysłu Darwina. Taka „kumulatywistyczna” wizja trudna jest do utrzymania w konfrontacji $\mathrm{z}$ materiałem historycznym, przedstawionym $\mathrm{w}$ omawianej publikacji, świadczącym o tym, że teoria doboru naturalnego nie była aż tak wpływowa, jak się to powszechnie uważa, a nawet przez długi czas była ignorowana przez społeczność naukową. Ponadto niespójność ewolucjonizmu biologicznego (inne koncepcje gatunku implikowane przez różne ontologie i metodologie) zrodziła zasadniczy problem konceptualny - dwa różne pojęcia gatunku, funkcjonujące w jednej teorii, co, zdaniem autora, stało się zasadniczym powodem odrzucenia teorii ewolucji w okresie „zaćmienia” na rzecz teorii nie borykających się z tego rodzaju niespójnością. Dobrze, że w publikacji M. Wagnera wyraźnie wybrzmiał ten wątek, bo dzięki temu możemy przekonać się, jak to, co dziś jest uznawane za paradygmat ewolucjonistyczny, wymagało (i nadal wymaga) przekształcenia, doprecyzowania i uszczegółowienia w zakresie treści i znaczenia używanych pojęć oraz leżących u ich podstaw wyobrażeń, poglądów i wiedzy. 


\title{
(REV.) MICHAŁ JAKUB WAGNER, "INTERPRETACJE ROZWOJU BIOLOGII
}

\section{EWOLUCYJNEJ NA PRZEŁOMIE XIX I XX WIEKU” [“INTERPRETATIONS OF THE} DEVELOPMENT OF EVOLUTIONARY BIOLOGY IN THE LATE 19TH AND EARLY 20TH CENTURIES"], LIBER LIBRI, WARSZAWA 2020, PP. 332

\begin{abstract}
The author of this publication undertook the task of analyzing the interpretations of the "eclipse of Darwinism" proposed so far in order to determine to what extent they correspond to reality. Having made his findings in this regard, he concluded that none of them adequately accounted for the collapse that struck Darwin's theory during that period. Therefore, he decided to propose his own interpretation of the "eclipse of Darwinism," he refers mainly to philosophical determinants of the Darwinian theory of evolution.
\end{abstract}

Keywords: theory of evolution; Darwinism; evolutionary biology; eclipse of Darwinism

\footnotetext{
ADAM ŚWIEŻYŃSKI

Uniwersytet Kardynała Stefana Wyszyńskiego w Warszawie, Instytut Filozofii

(Cardinal Stefan Wyszyński University in Warsaw, Institute of Philosophy)

ORCID https://orcid.org/0000-0003-0430-4530

a.swiezynski@uksw.edu.pl

DOI 10.21697/spch.2021.57.R.03

${ }_{\text {OPEN }} \partial_{\text {aCCESS }}$ (c) (1) $\Theta$

Tekst jest udostępniany na zasadach licencji Creative Commons (CC BY-ND 4.0 Międzynarodowe).

Zgłoszono: 04/08/2021. Zrecenzowano: 19/08/2021. Zaakceptowano do publikacji: 06/09/2021.
} 